\title{
Chinese EFL Learners' Motivation Mediated by the Perceived Teacher Factors-Different Voices from Different Levels of Education
}

\author{
Chang Liu \\ Department of English, City University of Hong Kong, Hong Kong SAR, China
}

\begin{abstract}
This study examines Chinese EFL learners' motivation at different educational levels and their perceptions of teacher-related motivators. The questionnaire survey and follow-up interview were administrated among students from junior high schools, senior high schools and universities, and the results reveal the impact of teachers' perceived commitment on students' motivational level together with the most motivating teacher factors identified by three student groups. With the English learning experience accumulating, students tend to place less value on teachers' emotional support whereas rate teaching competence as the key factor for their motivation. Also, striking findings related to learners' motivation at the tertiary level have been elucidated: first, compared with young learners, university students not only do not think that teachers' commitment would exert much influence on their motivation but also show a tendency to follow this belief in action. Second, teachers' capacity for knowledge transfer is rated highest by them as the most crucial motivator rather than the communicative teaching style, which is instead overwhelmingly prioritized by secondary school learners. Based on these findings, recommendations on motivational instruction for English teachers at different levels of education are suggested.
\end{abstract}

Index Terms-EFL learning motivation, teacher-related motivators, teaching commitment, motivational strategies

\section{INTRODUCTION}

Motivation is an inevitable concept in second or foreign language acquisition (SLA/ FLA), and the last few decades have witnessed a tangible improvement upon the investigation on the role of motivation in the arduous process of SLA (e.g., Dörnyei, 1994; Wi \& Joh, 2010; Zarei, Ahour \& Seifoori, 2020). Studies have shown that among all factors affecting learners' second or foreign language (L2/ FL) motivation, the language teacher is one determinant (Dörnyei, 1994; Kikuchi, 2009), and based on this preliminary observation, further investigation into what teachers say, do or are like can capture learners' interests has also been conducted, contributing to the findings that some prominent qualities of language teachers like good subject knowledge, teaching competence, interactive skills and classroom management could exert a profound impact on students' engagement and persistence in English learning (Miller,1987; Borg, 2006; Koç, 2012).

However, what noteworthy is that these identified teacher factors must be mediated by learners' perceptions before they impact learners' motivation. In other words, students' L2 motivational level is subject to how they feel about the language teacher (Williams \& Burden, 1997), like whether the teacher is perceived as an ideal model of English speaker, learner, mentor, consultant or facilitator. Therefore, the decision on which teacher factors can serve as motivators depends on students' appraisal of teachers' personal qualities and teaching behaviors or events (Wen, 1997; Matsumoto, 2010).

To further the research agenda into how English learners perceive the language teacher's motivational instruction in the field of language pedagogy, and given that the majority of previous studies relevant to this topic either merely involved the attitudes of one particular learner group or compared the views between students and teachers (e.g., Jacques, 2001; Sakai \& Kikuchi, 2008; Kikuchi, 2009), whereas seldom accommodated the diverse needs of different learner groups, leaving the teacher-related motivators perceived by students from different levels of education still a puzzle, the current empirical study intends to address this research gap by inquiring into the motivation of Chinese EFL learners from different educational levels and their perceptions of teachers as the affecting factors.

\section{LITERATURE REVIEW}

L2/ FL motivation can promote students' language learning willingness, pushing them to initiate and work relentlessly to get the learning objectives (Masgoret \& Gardner, 2003). With all the potential for facilitating students' English learning, motivation has always been the major concern for language educators and researchers, contributing to a growing body of studies about the specific motivators related to language acquisition (e.g., Oxford \& Shearin, 1994; Liu, 2020). Also, among all identified factors, teacher-related ones are predominant, and even more so in the 
educational context where English is learned mainly through classroom teaching and teachers' instruction is the most crucial, if not the sole, source for students to acquire knowledge (Wen \& Clément, 2003), just like the case for EFL learning in China. Therefore, concentrated attention should be drawn to explore the teacher-related motivators situated in the classroom-based English learning context. For example, a seminal study by Williams and Burden (1997) found that the motivators concerned with teachers perceived by learners were mostly relation-oriented, like teachers' feedback, rewards, praise and punishment, which emphasized teachers' facilitative roles in boosting students' affective learning. Also, such research finding was echoed by Scott et al. (2002) who claimed that teachers' interpersonal communication styles (e.g., responsive, friendly) could fuel students' participation in English class and increase their learning motivation.

In addition to affective characteristics, other teacher factors like teaching skills, academic knowledge, personalities and classroom management have also been highlighted by the studies in the field of EFL motivation (e.g., Borg, 2006; Nikitina \& Furuoka, 2009). According to Usman and his colleagues (2016), teachers' cognitive competence, namely whether or not language teachers could excel in giving lessons and teaching English as a subject, influenced how they were perceived by students and thus on students' learning motivation. Furthermore, language teachers' subject knowledge and personality traits like gentleness and amiability were also reported as major constructs affecting learners' motivation (Borg, 2006; Miller, 1987).

To conclude the identified teacher factors, Göksel and Rakıcığlu-Söylemez (2018) have outlined a category comprising four dimensions: academic knowledge, personality, socio-affective skills and teaching competence. Academic knowledge concerns teachers' subject knowledge and personality refers to teachers' personality traits. Socio-affective skills are teachers' capabilities to establish positive relations with students and their attitudes towards the teaching profession, for example, whether they can consider personal differences between students and engage in teaching, and lastly, teaching competence deals with teachers' effective use of teaching methods and materials. The detailed description of each category, based on which the most motivating teacher factors perceived by different student groups will be measured by the questionnaire in the current study, is given in Table I.

TABLE I.

Detalled Description Of Four CATEgories Of Teacher-Related Motivators Measured In THe Study

\begin{tabular}{|c|c|c|c|}
\hline $\begin{array}{l}\text { Academic } \\
\text { competence }\end{array}$ & \multicolumn{2}{|c|}{$\begin{array}{l}\text { Professional } \\
\text { knowledge and } \\
\text { development }\end{array}$} & $\begin{array}{l}\text { be confident with his/her language skills and content knowledge, know } \\
\text { grammar well, have a wide vocabulary and good pronunciation, have earned } \\
\text { a reputation in the research field }\end{array}$ \\
\hline Personality & \multicolumn{2}{|c|}{ Personality traits and teacher roles } & $\begin{array}{l}\text { Be patient and approachable, be positive towards life; have a good physical } \\
\text { appearance, could be a good organizer and set a role model for his/her } \\
\text { students }\end{array}$ \\
\hline \multirow[t]{2}{*}{$\begin{array}{l}\text { Socio-affective } \\
\text { skills }\end{array}$} & \multicolumn{2}{|l|}{ Social context } & $\begin{array}{l}\text { Consider the differences between students, know students well, motivate and } \\
\text { communicate with them }\end{array}$ \\
\hline & \multicolumn{2}{|c|}{ Attitudes toward the profession } & Engage with the profession, have a strong sense of devotion to the job \\
\hline \multirow[t]{5}{*}{$\begin{array}{l}\text { Teaching } \\
\text { competence }\end{array}$} & \multirow[t]{2}{*}{$\begin{array}{l}\text { Instructional } \\
\text { process }\end{array}$} & $\begin{array}{l}\text { Communicative } \\
\text { methods }\end{array}$ & $\begin{array}{l}\text { Have effective communication skills, create student-centered classes, use } \\
\text { different types of classroom activities, methods and approaches to create } \\
\text { various opportunities for students to practice English }\end{array}$ \\
\hline & & Knowledge transfer & $\begin{array}{l}\text { Have prepared well before the class, can stand out the thematic knowledge, } \\
\text { explain grammar or knowledge points clearly and logically, give specific } \\
\text { instruction and feedback before and after student activities in class }\end{array}$ \\
\hline & \multicolumn{2}{|c|}{ Instructional resources and materials } & $\begin{array}{l}\text { Use visual, printed and authentic materials actively, make use of the } \\
\text { projector and the computer in the classroom }\end{array}$ \\
\hline & \multicolumn{2}{|c|}{ Classroom management } & $\begin{array}{l}\text { Manage the class well, have effective classroom management skills, can } \\
\text { control students' anxiety and grab their attention }\end{array}$ \\
\hline & \multicolumn{2}{|c|}{ Evaluation and feedback } & $\begin{array}{l}\text { Give personalized feedback and future learning objectives according to } \\
\text { students' learning performances }\end{array}$ \\
\hline
\end{tabular}

On the other hand, regarding the research insight into the demotivators relative to teachers' misbehavior, Kearney et al. (1991) initiated this topic by examining college students' description of teacher behavior distracting them from the English learning, and 28 categories of teacher misbehavior generally summarized as incompetence, offensiveness and indolence were identified as shown in Table II. In the same series of studies, teachers' annoying personalities, lack of teaching skills, boring lecturing styles (e.g., giving lessons that put overdue stress on grammar), and the inappropriate use of teaching materials were also reported as the demotivators by learners at high schools (Sakai \& Kikuchi, 2009; Nikitina \& Furuoka, 2009). 
TABLE II.

CATEGORIZATION OF TEACHER MisBEHAVIOR IN KEARNEY ET AL. (1991)

\begin{tabular}{lll}
\hline Categories & Definition & Misbehavior \\
\hline Incompetence & $\begin{array}{l}\text { Lack of basic teaching skills; behave in } \\
\text { a way that interferes with teaching goals } \\
\text { and students' learning. }\end{array}$ & $\begin{array}{l}\text { Confusing lectures, apathetic to students, unfair testing, information overload, do } \\
\text { not know the subject matter well, unrecognized accents, bad grammar/spelling. }\end{array}$ \\
Offensiveness & $\begin{array}{l}\text { Humiliate, insult and publicly } \\
\text { embarrasses students. }\end{array}$ & $\begin{array}{l}\text { Sarcasm, verbally abusive, unreasonable arbitrary rules, sexual harassment, } \\
\text { negative personality, favoritism/prejudice. } \\
\text { Absent-minded, from whom students } \\
\text { Andoncent, tardy, unprepared/disorganized, deviate from the syllabus, information } \\
\text { fanderload. }\end{array}$ \\
\hline
\end{tabular}

Based on the above analysis, it can be seen that though there has been a growing consensus about the perceived teacher factors which may affect English learning motivation, they are mostly extracted from the studies that examine learners' perception or motivational state at a certain educational point rather than compare learners' attitudes between different levels of education. This is extremely puzzling as learners' FL motivation is not static or stable. Instead, it is subject to change with the accumulation of learning experience (Cohen \& Dörnyei, 2002), indicating that the perception of or expectation towards language teachers for junior high school students would be very different from that for senior high school or university students. Therefore, it is necessary to explore the differences in the most crucial teacher-related motivators perceived by students at different levels of education. To answer this question, Matsumoto (2011) found that students at elementary level tended to be motivated by teachers' non-verbal interaction with them, signifying the importance of teachers' perceived personality to teenagers' EFL learning, whereas for students at higher school stages, teaching-related ones were given more weight. Besides, in the study conducted by Hamada (2011) which investigated the change of demotivators perceived by Japanese students over the secondary school period, it was found that factors related to teachers' affective characteristics and teaching skills were rated to be more demotivating by the senior high school students than by the junior high school students.

However, for studies concerned with EFL learners' motivation mediated by their perception of teachers in the Chinese educational context, those comparing different voices of students from different educational levels have been scarce. With participants coming from two types of colleges--comprehensive and technical colleges in Taiwan, Hsu's (2013) study revealed students' attitudes to teachers' misbehaviors and the effects of these misbehaviors on students' motivation for English learning. It was suggested that students' motivation would be frustrated if the English teacher gave boring and unprepared lectures, explained unclearly, ignored students' needs and failed to notify students in time. These findings support Dörnyei (1994)'s claim that teachers' commitment to teaching, to be more specific, the model teachers establish for students by showing how they value L2 learning as an enriching experience themselves and how seriously they take students' learning process, is specifically pertinent to students' motivation for and investment into English learning, and conversely, teachers' indolence or lack of devotion to their job would be "the fastest way to undermine students' motivation" (p. 282). Since up to date, few studies have investigated that for Chinese EFL learners at different educational levels, whether and to what extent do their FL motivational levels change correlating with teachers' perceived commitment levels, and how they would regard the most important teacher-related motivators differently, the current study, with the overarching purpose to explore Chinese EFL learners' motivation at different levels of education and their perceptions of teachers as the affecting factors, is an attempt to bridge the gap by addressing the following questions:

1. Do students at junior high schools, senior high schools and universities have different levels of English learning motivation?

2. If yes, to what extent is the difference caused by teachers' different perceived levels of commitment? Or is there any correlation between students' motivational level and their perception of teachers' commitment?

3. How about the differences among the three learner groups' perceptions of the most motivating teacher-related factors when factors are measured in terms of four dimensions: academic knowledge, personality, socio-affective skills and teaching competence?

\section{METHODOLOGY}

To provide an insight into different learner groups' EFL motivation mediated by their perceptions of teachers, a questionnaire survey and follow-up semi-structured interview were used to collect quantitative and qualitative data in this study.

\section{A. Participants}

A total of 182 Chinese students learning English at different levels of education participated voluntarily in our research. The first learner group was 95 junior school students at the age of 13-15. The second group consisted of 54 senior school students with 6-8 years of English learning experience, and the last group, with 33 respondents, represented the undergraduate students. Having learned English for more than 9 years and been admitted to universities, they were at a relatively high level of English proficiency. Also, among these 182 participants, 84 were male and 98 were female, and since selected by a convenience sampling, they were concentrated in the northern area of China. However, with participants at three educational levels enrolling in different schools and having different English 
proficiency, the data obtained in the current research were to some extent unbiased and representative of student voices from diverse backgrounds.

\section{B. Instruments}

Participants completed one instrument, which was the questionnaire adapted from Matsumoto (2011) and Koç (2012). The questionnaire was constructed on the basis of the existing items or categories mainly for two reasons: first, it would be convenient for us to compare the results reached by other researches focusing on a similar topic. Second, the established categories and constructs had been employed and examined were considered more reliable than those which had not. The questionnaire was written in Chinese to be more reader-friendly, and it contained four major questions: (1) students' current motivational intensity for English learning, (2) students' perception of their teachers' level of commitment to the job, (3) students' degree of agreement about the positive relationship between their motivational level and teachers' commitment, and (4) the most dominant teacher-related motivators perceived by students in their current English learning. For questions 1 to 3, the five-point Likert scale ranging from strongly disagree (1) to strongly agree (5) was used to elicit students' responses, and in question 4, students were asked to select one teacher-related motivator affecting them most strongly from a list of eight provided by the questionnaire. Furthermore, the categories that the eight factors would fall into were set in advance according to the dimensions examined by the third research question, which were academic knowledge, personality, socio-affective skills and teaching competence (Göksel \& Rakıcıŏlu-Söylemez, 2018), and as mentioned above, the detailed statement of each factor on the questionnaire was shown by Table I. Also, the fourth question was open-ended as it allowed respondents to list other teacher factors perceived to be the most motivating yet not provided on the questionnaire.

To ensure the validity of the survey, the questionnaire draft was analyzed and checked by two invited colleagues who were masters in English studies and experienced English teachers. Based on their comments, some items were revised, modified or omitted. Then a pilot study was conducted among 10 students who had a similar background to our intended participants and would be excluded from the following formal survey. Their advice was also taken to resolve any ambiguities or misunderstandings and to improve the comprehensibility of the questionnaire.

\section{Data Collection Procedures}

Questionnaires were distributed to subjects on the Internet, and the objectives of our study were informed at the beginning of the survey. It was also indicated to our respondents that their confidentiality and voluntary participation in the survey would be assured, by which the author has fulfilled the ethical procedures in researching human participants. Data were collected as soon as participants fulfilled the survey. In the following data analysis, if anything worth attention was discovered in the collected questionnaires and the participants also left their phone numbers or emails to show a willingness to be contacted, they would be invited to join the follow-up interview.

\section{Data Analysis}

To get more reliable answers to our research questions, the obtained data were first examined by the author. Answers had been given carelessly in an extremely short period (within 10 seconds) were abandoned. Then the remaining data were analyzed by SPSS 17.0. Kendall's tau was computed to identify the relationship between the subjects' motivational level and the perceived teachers' commitment for the whole sample and at each study level, and Chi-square test or Fisher's exact test was used to analyze the differences in the most significant teacher-related motivators chosen by students from different levels of education. Lastly, the descriptive data got from the interview were used to validate participants' responses to the questionnaire and to interpret the quantitative data when necessary.

\section{RESUlts AND Discussion}

\section{A. Different Levels of English Learning Motivation between Students at Junior High Schools, Senior High Schools and} Universities

TABLE III.

STUDENTS' MOTIVATIONAL LEVEL

\begin{tabular}{cccccccc}
\hline Educational level & Mean & SD & 1 & 2 & 3 & 4 \\
\hline Junior high school & 3.13 & .743 & $6.3 \%$ & $9.5 \%$ & $56.8 \%$ & $20 \%$ & $7.4 \%$ \\
Senior high school & 2.80 & .752 & $5.6 \%$ & $29.6 \%$ & $44.4 \%$ & $20.4 \%$ & $0 \%$ \\
University & 3.27 & .939 & $9.1 \%$ & $9.1 \%$ & $42.4 \%$ & $24.2 \%$ & $15.2 \%$ \\
Overall & 3.05 & .863 & $6.6 \%$ & $15.4 \%$ & $50.5 \%$ & $20.9 \%$ & $6.6 \%$ \\
\hline
\end{tabular}

Kruskal-Wallis test: $H=29.077, d f=2, \mathrm{p}<.001$.

The statistical results for the first research question were provided in Table III. First, the Kruskal-Wallis Test showed that there was a significant difference in the motivational capacity of students from different levels of education $(H=29.077, d f=2, p<.001)$. In addition, it can be seen that university students' ( $n=33$ ) English learning motivation was the highest among the three with the mean score at 3.27, whereas the senior high school students (n=54) were the least motivated $(M=2.80)$. Besides, there were $39.4 \%$ university students thinking that they were either motivated or highly motivated to learn English at the current stage, whereas this percentage for senior school students 
was as small as $20.4 \%$ with even not a respondent among this group thinking himself or herself was strongly motivated to learn English currently. As for junior high school students, they were at the intermediate level and the proportion of participants who thought their English learning motivational level was relatively high (27.4\%) was larger than the proportion of those believing they were less motivated $(15.8 \%)$.

Studies on L2 demotivation can shed light on why students at different educational levels were motivated differently. For senior high school students, they were least motivated because they were more likely to confront the increasingly difficult learning contents, heavy workload and the accumulated effect of the experience of failure (Hamada, 2011). To take the difficult learning contents as an instance, given that grammar, one major obstacle that senior high school students encounter in English learning, is not so stressed in junior high school period, students who have not learned grammar in depth are more likely to have difficulty in understanding the structure of English when entering the senior high school, which partly accounts for the lowest motivational level that senior high school participants showed in the current study.

\section{B. Correlation between Teachers' Perceived Level of Commitment and Students' Motivational Intensity}

TABLE IV.

STUdents' MOTIVATIONAL INTENSITY AND THE PERCEIVED TEACHERS' COMMITMENT LEVEL

\begin{tabular}{llllll}
\hline & & Junior high school & Senior high school & University & Total \\
\hline Ss' Motivation & Mean & 3.13 & 2.80 & 3.27 & 3.05 \\
& $\mathrm{~N}$ & 95 & 54 & 33 & 182 \\
& SD & .914 & .833 & 1.126 & .944 \\
Ts' Motivation & Mean & 4.15 & 4.00 & 3.15 & 3.92 \\
& $\mathrm{~N}$ & 95 & 64 & 33 & .939 \\
& SD & .743 & .752 & .939 & .863 \\
\hline
\end{tabular}

The intensity of students' learning motivation and the perceived level of teachers' commitment at different levels of study were provided in Table IV. It was shown that the mean scores for both junior and senior high school English teachers $(\mathrm{M}=4.15, \mathrm{M}=4.00$ respectively) were conspicuously higher than their university counterparts $(\mathrm{M}=3.15)$. At the same time, the mean for respondents' $(\mathrm{N}=182)$ overall perception of teachers' motivation was 3.92, obviously higher than the mean for learners' own motivational level $(\mathrm{M}=3.05)$, and interestingly enough, though this result was particularly valid for senior high school students who believed that their teachers' average commitment level ( $\mathrm{n}=54$, $M=4.00)$ was much higher than their own motivation $(n=54, M=2.80)$, it could not represent the case at the tertiary level, as university students' motivation capacity $(n=33, M=3.27)$ on average was higher than their teachers' perceived level of commitment $(n=33, M=3.15)$.

Next, the correlation between students' motivational level and teachers' perceived commitment was analyzed by Kendall's tau-b correlation. The results indicated a positive relationship based on the overall sample and at the junior high school level, but such correlation was not found at the senior high school and university levels (Table V).

TABLE V.

Kendall's TAU BetweEn TEACHERS’ PERCEIVED COMMITMENT AND STUDENTS' MOTIVATIONAL LEVEL

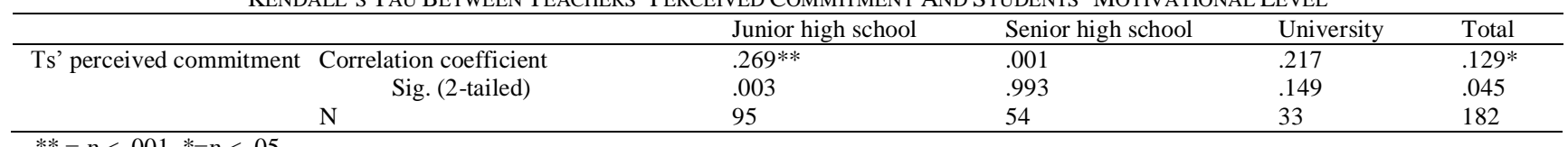

$* *=p<.001, *=p<.05$

To account for the statistical results mentioned above, first, the low mean score rated for university teachers' commitment relative to the secondary school teachers' can be explained by the interview results that some university students thought their professors failed to strike a balance between the language teaching and research, concentrating too much on their own research yet less devoted to teaching, and such impression resulted in "the profile of stereotypic, absent-minded and indolent college teachers" (Kearney et al., 1991, p. 323) from whom students did not feel they could acquire as much knowledge as they expected. Moreover, considering that in Xiang and Borg's study (2015), evidence of "exhaustion, lack of appreciation, and a reduced sense of accomplishment" (p. 110) which leads to burnout has been identified among college teachers, and the negative impact of teachers on university EFL learners' motivation has even been noted explicitly by Kikuchi (2019), we can infer from the current survey that university teachers, compared with their counterparts in secondary schools, are more susceptible to the reduced commitment and investment into pedagogical duties.

Furthermore, the results of students' motivation in relation to the perceived level of teachers' devotion concur with some of the earlier research findings. First, given that the literature in favor of the role of teachers' positive modeling and increased investment in enhancing learners' motivation, especially when the learners are young teenagers (e.g., Csizér \& Dömyei, 2005), the present study can be considered as additional support to this line of research. Second, the results echo the findings of Matsumoto (2011), showing that students tend to rate teachers' perceived level of commitment higher than their own motivational intensity, and this might partly be attributed to the fact that students somehow have an instinct for pleasing their teachers (Dömyei, 1994). In the current study, though participants were assured of the anonymity of the survey, we still could not exclude the possibility that respondents, teenage respondents 
in particular, rated their teachers to be highly devoted instinctively or subconsciously. However, in the light of the scores rated by secondary school students for their language teachers are higher than $3.00(\mathrm{M}=4.15$ and $\mathrm{M}=4.00$, respectively), signifying that teachers are believed to be more than moderately devoted to the job, it is safe to conclude that English teachers at the secondary school level are mostly committed and recognized to fulfill their teaching obligation.

Lastly, students' response to the third questionnaire question which elicited the extent to which respondents agreed on the statement that English teachers' commitment affected their motivation for English learning also proves the impact of teachers' perceived commitment on students' motivational level. As shown by Table VI, university respondents showed the least extent of agreement to the statement $(M=3.61)$ relative to the perception of junior $(M=3.76)$ and senior high school participants $(M=3.69)$. Also, compared with the senior high school students, learners at junior high schools had a much smaller standard deviation of 0.896 , signifying that they had a very similar higher level of agreement on the fact that the language teacher's commitment would affect their learning motivation, thus validating the previously-mentioned finding that young learners are more inclined to be influenced by teachers in their language learning process. On the contrary, the lowest mean score given by university students indicates that they as adult learners are more self-disciplined and less dependent on teachers' push and supervision, consistent with the prior finding that compared with teenager learners, university learners would be more likely to have a relatively high level of motivation in English learning even if without the presence of a committed teacher.

TABLE VI.

\begin{tabular}{lllll} 
STUDENTS' PERCEIVED LEVEL OF AGREEMENT ABOUT THE IMPACT OF TEACHERS' COMMITMENT ON THEIR MOTIVATIONAL INTENSITY \\
\cline { 2 - 5 } & Junior high school & Senior high school & University & Total \\
\hline Mean & 3.76 & 3.69 & 3.61 & 3.71 \\
N & 95 & 54 & 33 & 182 \\
SD & .896 & 1.241 & 1.059 & 1.034 \\
\hline
\end{tabular}

\section{Students' Perception of the Most Motivating Teacher-related Factors}

What teacher-related factor, then, was perceived by students as the determinant of their motivation for English learning? In response to this question, 6 students believed that no teacher factor could influence them so they were excluded from the analysis, and no students responded to this open-ended question by giving unmentioned factors. The remaining 176 students' response was categorized into four factors: socio-affective characteristics, teaching competence, academic knowledge and personality. As for the statistical analysis of the data, to start with, since the Chisquare test generally requires a minimum frequency for each cell to be five, but our survey results showed that some cells fell below five due to the small sample, a Fisher's exact test was used instead, from which a significant difference in the most motivating factors related to teachers perceived by students from three levels of education $(p=.025<.05)$ has been found. Moreover, teaching competence featured prominently in the result for overall respondents (58\%), especially for university respondents $(62.5 \%)$, and socio-affective characteristic $(19.9 \%)$ was the second most cited dimension, followed by personality (12.5\%) (see Table VII).

TABLE VII

Students’ Perception Of The Most MOtivating TeACHER-RElated FACTORS

\begin{tabular}{|c|c|c|c|c|c|c|}
\hline \multicolumn{2}{|c|}{ Educational level } & \multicolumn{4}{|c|}{ Teacher factors } & \multirow[t]{2}{*}{ Total } \\
\hline & & $\begin{array}{l}\text { Academic } \\
\text { knowledge }\end{array}$ & Personality & $\begin{array}{l}\text { Socio-affective } \\
\text { characteristics }\end{array}$ & $\begin{array}{l}\text { Teaching } \\
\text { competence }\end{array}$ & \\
\hline Junior high school & $\begin{array}{l}\text { count } \\
(\%)\end{array}$ & $\begin{array}{l}5 \\
(5.3 \%)\end{array}$ & $\begin{array}{l}9 \\
(9.6 \%)\end{array}$ & $\begin{array}{l}25 \\
(26.6 \%)\end{array}$ & $\begin{array}{l}55 \\
(58.5 \%)\end{array}$ & 94 \\
\hline Senior high school & $\begin{array}{l}\text { count } \\
(\%)\end{array}$ & $\begin{array}{l}6 \\
(12.0 \%)\end{array}$ & $\begin{array}{l}11 \\
(22 \%)\end{array}$ & $\begin{array}{l}6 \\
(12 \%)\end{array}$ & $\begin{array}{l}27 \\
(54 \%)\end{array}$ & 50 \\
\hline University & $\begin{array}{l}\text { count } \\
(\%)\end{array}$ & $\begin{array}{l}6 \\
(18.8 \%)\end{array}$ & $\begin{array}{l}2 \\
(6.3 \%)\end{array}$ & $\begin{array}{l}4 \\
(12.5 \%)\end{array}$ & $\begin{array}{l}20 \\
(62.5 \%)\end{array}$ & 32 \\
\hline Total & $\begin{array}{l}\text { count } \\
(\%)\end{array}$ & $\begin{array}{l}17 \\
(9.7 \%)\end{array}$ & $\begin{array}{l}22 \\
(12.5 \%)\end{array}$ & $\begin{array}{l}35 \\
(19.9 \%)\end{array}$ & $\begin{array}{l}102 \\
(58.0 \%)\end{array}$ & 176 \\
\hline
\end{tabular}

Despite that teaching competence was most valued by all the three groups, other teacher dimensions were given different importance by different learner groups. To elaborate upon it, junior school respondents placed the second highest value on teachers' socio-affective characteristics $(26.6 \%)$, followed by personality $(9.6 \%)$, whereas students at senior high schools believed that compared with socio-affective characteristics $(12 \%)$, teachers' personality $(22 \%)$ would be a stronger motivator for their English learning. They expected that the English teacher was genial, kind, approachable and had a positive attitude to teaching and life as well, serving as a guide and role model for their English learning. Lastly, university English learners regarded teachers' academic knowledge and research ability (18.8\%) as the second most motivating source. Therefore, it can be found that as respondents' educational level went higher, the total percentage for teachers' socio-affective characteristics and personality decreased whereas the percentage for teaching competence increased.

Results of the current study demonstrate the richer emotional needs that learners at junior high school, a lower educational level, have for their teachers but a stronger preference for teachers' pedagogical skills over the personal 
qualities expressed by the university learners, both of which reinforce Matsumoto's (2011) finding that "L2 learners tend to shift the importance in teacher-related factors from personality-based to teaching-based ones as they develop proficiency" (p. 47). As beginning learners who lack knowledge foundation and communicative skills, junior high school students are not so capable to comprehend what teachers are saying in English and to independently assess teachers' teaching methods and skills, thus compared with learners of higher study levels, it is more likely for them to focus on teachers' ability to establish a good rapport with students which connects with their emotional needs more directly and doesn't need background language knowledge and skills to interpret. However, for students at university levels, professional skills are valued since they can get the point of teachers' instruction and to assess teachers' use of teaching resources and techniques, ways to impart knowledge and organize student activities as indications of their teaching competence. Therefore, the discrepancies in the most dominant teacher-related motivators perceived by three groups are caused by students' different levels of English proficiency and emotional development.

In addition, since two of the five teacher-related dimensions, teachers' socio-affective characteristics and teaching competence, had more than one subcategory tested by the questionnaire, there was a need to delve into the varying degrees of significance given by different groups to each of the specific factors. For one thing, with regard to teachers' socio-affective characteristics, teachers' positive attitudes to individual students and willingness to pay close attention to students' learning were higher on the list regardless of the educational levels (see Table VIII), indicating that both secondary and university students would be more easily affected by teachers' attentiveness to their personalized learning needs than by teachers' general devotion to the job. This finding concerning students' relationship-oriented expectations to their teachers has already been reported by Park (2006) and Nikitina and Furuoka (2009), both of which show that though situated in Asia where teacher-centered and hierarchical culture norms prevail, students still have emotional needs in their relationship with teachers and value teachers' good interpersonal skills. Therefore, when considering a stimulus for students' learning motivation, it is preferable for teachers to start the change by establishing an emotional connection with individual students.

TABLE VIII.

Students' Perception Of The Most AfFecting Motivators CONCERnEd With Teachers' Socio- AfFeCtive Characteristics

\begin{tabular}{lcll}
\hline \multicolumn{2}{c}{ Educational level } & \multicolumn{2}{c}{ Socio- affective characteristics } \\
\cline { 3 - 4 } & & Social context & Attitudes toward the profession \\
\hline Junior high school & $\begin{array}{c}\text { count } \\
(\%)\end{array}$ & $(60 \%)$ & 10 \\
Senior high school & count & 4 & $(40 \%)$ \\
& $(\%)$ & $(66.67 \%)$ & 2 \\
University & $\begin{array}{c}\text { count } \\
(\%)\end{array}$ & 4 & $(33.33 \%)$ \\
Overall & count & $(100 \%)$ & 0 \\
& $(\%)$ & 23 & $(0 \%)$ \\
& $(65.71 \%)$ & 12 \\
\end{tabular}

For another, when subcategories of teaching competence are concerned, the Fisher's exact test showed a significant correlation between the learners' levels of education and the perceived most dominant motivators related to teachers' teaching performance $(p=.033<.05)$. Second, as indicated by Table IX, teachers' instructional process was placed highest by all the three respondent groups whose responses to the fourth question fell into the category of teachers' teaching competence, accounting for $81.83 \%, 59.26 \%$ and $85 \%$ respectively. Besides, something interesting can be found by an inquire into the preferred instructional process among the three groups, since communicative-based teaching $(52.73 \%)$ was far more valued than knowledge transfer $(29.10 \%)$ by junior high school participants, whereas the case for university learners was that more importance was attached on teachers' knowledge transfer (55\%) than communicative teaching styles $(30 \%)$. Such difference was also validated statistically by the Chi-square test which indicated a significant difference in the perceived most affecting motivational instruction between students at the junior high school and university level $\left(\chi^{2}=4.265, d f=1, p=.039<.05\right)$. Besides, compared with students from a lower level of education, university respondents tended to think that their teachers' classroom management ability had little or even no effect on their motivational level. 
TABLE IX.

Students' Perception Of THE MOSt AFFECTING Motivators CONCERnEd With TEACHING COMPETENCE

\begin{tabular}{|c|c|c|c|c|c|c|}
\hline \multirow[t]{3}{*}{ Educational level } & \multicolumn{5}{|c|}{ Teaching competence } & \multirow[t]{3}{*}{ Total } \\
\hline & \multicolumn{2}{|c|}{ Instructional process } & \multirow{2}{*}{$\begin{array}{l}\text { Instructional } \\
\text { resources and } \\
\text { materials }\end{array}$} & \multirow{2}{*}{$\begin{array}{l}\text { Classroom } \\
\text { management }\end{array}$} & \multirow{2}{*}{$\begin{array}{l}\text { Feedback } \\
\text { evaluation }\end{array}$} & \\
\hline & $\begin{array}{l}\text { communicative } \\
\text { method }\end{array}$ & $\begin{array}{l}\text { knowledge } \\
\text { transfer }\end{array}$ & & & & \\
\hline $\begin{array}{ll}\text { Junior high school } & \begin{array}{l}\text { count } \\
(\%)\end{array}\end{array}$ & $\begin{array}{l}29 \\
(52.73 \%)\end{array}$ & $\begin{array}{l}16 \\
(29.10 \%)\end{array}$ & $\begin{array}{l}3 \\
(5.45 \%)\end{array}$ & $\begin{array}{l}2 \\
(3.63 \%)\end{array}$ & $\begin{array}{l}5 \\
(9.09 \%)\end{array}$ & 55 \\
\hline $\begin{array}{ll}\text { Senior high school } & \text { count } \\
& (\%)\end{array}$ & $\begin{array}{l}8 \\
(29.63 \%)\end{array}$ & $\begin{array}{l}8 \\
(29.63 \%)\end{array}$ & $\begin{array}{l}9 \\
(33.34 \%)\end{array}$ & $\begin{array}{l}1 \\
(3.70 \%)\end{array}$ & $\begin{array}{l}1 \\
(3.70 \%)\end{array}$ & 27 \\
\hline University & $\begin{array}{l}6 \\
(30 \%)\end{array}$ & $\begin{array}{l}11 \\
(55 \%)\end{array}$ & $\begin{array}{l}2 \\
(10 \%)\end{array}$ & $\begin{array}{l}0 \\
(0 \%)\end{array}$ & $\begin{array}{l}1 \\
(5 \%)\end{array}$ & 20 \\
\hline $\begin{array}{c}\text { count } \\
(\%)\end{array}$ & $\begin{array}{l}45 \\
(44.12 \%) \\
\end{array}$ & $\begin{array}{l}33 \\
(32.35 \%) \\
\end{array}$ & $\begin{array}{l}14 \\
(13.73 \%) \\
\end{array}$ & $\begin{array}{l}3 \\
(2.94 \%) \\
\end{array}$ & $\begin{array}{l}7 \\
(6.86 \%) \\
\end{array}$ & 102 \\
\hline
\end{tabular}

The different preferences for teachers' instructional styles between learners at universities and secondary schools can be found from the survey results. Though secondary school students, especially junior high school students are prone to be motivated by the communicative teaching approach, university students would rather regard teachers' abilities to express themselves clearly and provide enough valuable guide or feedback as more effective motivators. As Hamada (2011) claims, most English teachers in Japanese high school nowadays still adopt grammar-translation and examination-oriented teaching methods, organizing few communication activities under the pressure of training students to perform well in exams. Unfortunately, this may also be the case for English lessons in China (Gao \& Huang, 2010). Though the CLT approach has been introduced to reform the traditional grammar-focused language teaching, shifting the focus to a more communicatively oriented one to guide students to use English meaningfully in authentic contexts, this goal has not been realized until now, especially at the secondary school level (Hu, 2002). Given that the examination is still the major measure of assessment and the grade-getting goal remains unchanged in the EFL context of China, it is not surprising to find that the secondary school respondents perceived teachers' communicative teaching styles as the most motivating factor, as it produces a more relaxing, non-intimidating classroom environment which stressful students enjoy. Whereas for adult learners in universities, the interview has revealed the twofold reasons for their values attached to teachers' ability for knowledge transfer. For one thing, in the face of professional expertise, they need teachers' explicit guide more urgently yet no longer pursue the appealing learning atmosphere as strongly as teenagers do, and for another, some of the university learners suppose that their instructors when adopting the communicative activities often overemphasize students' self-teaching but offer little scaffolding or tutorials, in which cases activities are misused by teachers as a way to shirk teaching responsibilities, so students would rather not choose the communicative teaching process in the survey, and value teachers' knowledge transfer instead. Such interpretation has not only validated the previously mentioned finding that university students are already capable of assessing teachers' professional performance, but also identified the potential problems of the implementation of studentcentered CLT exported from western in the educational context of China, heightening the significance of pedagogical suggestions mentioned in the next section.

\section{CONCLUSION}

\section{A. Implications of the Study}

In this study, the roles of teachers in motivating Chinese EFL learners' have been supported consistent with the previous research (e.g., Alrabai, 2016; Lee, Gardner \& Lau, 2019; Zarei, Ahour \& Seifoori, 2020), and some insightful findings about the perceived varying degrees of impact of teachers' commitment, socio-affective skills, teaching competence, academic knowledge and personality on learners' motivation at different levels of education, varying from junior high school to university have also been reported to add to the existing literature. To conclude our findings more specifically, first, a positive correlation has been identified between the teachers' perceived level of commitment and students' learning motivational intensity for the whole sample, whereas for university students, they do not think that teachers' commitment would exert as much influence on their motivation as believed by the secondary school learners since though they themselves are the most strongly motivated in English learning among the three groups, their teachers are perceived as the least devoted to teaching, indicating a tendency for adult learners to follow their belief in the impact of teachers' devotion in the actual learning process. Second, the probe into the most motivating teacher factors perceived by learners at different educational levels has revealed that compared with university students, secondary school students attach more importance on teachers' communication-based aspects, like personality traits, socio-affective characteristics and the use of communicative activities in class, whereas university respondents with a comparatively high level of English proficiency tend to rate teachers' teaching competence as the top priority when the determinant of their English learning motivation is concerned. It is also noteworthy that the communicative teaching styles, though favored by the secondary school students, are not so stressed by university students, who instead consider teachers' sufficient knowledge transfer to be more crucial. These findings, while based on the groups of learners under investigation in the current study, are of broader relevance to EFL teaching at both secondary and tertiary level in educational situations similar to that of China, suggesting that teachers can serve as motivators for 
students' English learning only if they adjust the strategies in accordance with students' different proficiency levels, learning needs and developmental stages. Specifically speaking, the following pedagogical implications can be considered:

1. Given that language teachers' professional teaching performance is considered by students to be overwhelmingly important and communicative teaching methods are stressed by secondary schools learners in particular, language teachers should abandon the traditional teaching monologue, increasing students' participation in class through interactive activities like game-based grammar learning and the integration of online English forums, blogs, mobile learning and video-making projects into the curriculum (Fithriani, 2018; Jiang \& Luk, 2016). Most importantly, teachers while designing student activities must incorporate scaffolding and tutorials as indispensable parts. As noted by Jacobs (2013), no students would attribute the motivating power of communicative methods solely to such activities as the video-making project, which advises teachers against the assumption that the use of interactive activities in classroom teaching is innately motivating and can be employed without the knowledge input and teachers' assistance. Instead, they are expected to instruct in the skills or knowledge to be exercised in the self-learning process and offer help during the peer interaction. Also, teachers can group students heterogeneously, giving students of different backgrounds and abilities a chance to capitalize on their own talents and tap into the expertise of others (Jiang \& Luk, 2016), thereby reducing the perceived difficulties and demotivators arising from the activities.

2. In response to junior high school students' expectation that language teachers can build a good rapport with them and attend to their emotional needs, English teachers at the secondary school level should adjust their self-important mindsets as the absolute authority and strict manager for students. Instead, they can employ various strategies to project themselves as friends willing to establish emotional attachment with students, for example, by observing individual students in class and giving support (McEowna \& Takeuchib, 2014), by redressing their face-threatening instructional feedback via the use of encouraging words and hedges (Amiryousefi \& Geld, 2019), and by tailoring different homework or in-class student activities for students of different levels of English proficiency and foreign language anxiety to meet their cognitive needs (Matsuda \& Gobel, 2004).

3. As findings especially related to language teachers as the motivational sources at the tertiary level have been provided in this study, strategies on how to motivate university students' English learning should also be informed in particular. First, it is noted that though nowadays learners' autonomy has been advocated a lot, the significance of teachers' autonomy, their use of L2 motivational strategies and connection with students in promoting students' learning abilities should by no means be underestimated (Little, 1995; Dömyei \& Csizér, 1998). Moreover, special attention should be given to the student-centered CLT class especially in the Asian EFL learning context to examine whether teachers' roles have been marginalized yet students' roles been magnified improperly. If students can decide the teaching objectives, the progression of English lessons and the classroom discourse whereas teachers only serve as facilitators, helpers and consultants, it seems that the advantages of school education over self-teaching, which is more planned, organized, efficiency-oriented and led by the educational practitioners would not be fully manifested (Wen, 2015), making advanced learners acquire and improve a little. Also, given that the imported teaching philosophy of CLT has been raised based on the western learning culture characterized by individualism, whether it is applicable to Chinese traditional cultural environment, can a sudden shift from the teacher-centered class to the absolute studentcentered one be accepted by students and can the competence-based interactive teaching methods take up the moralizing function to cultivate the students towards the right direction are issues worth considering before we employed the CLT. At this point, English teachers can try to adopt the learning-centered teaching approach which is raised based on the Chinese pedagogical context and featured by maximizing students' knowledge input, emphasizing the exercise of productive skills and assessing students' learning effects in time (Wen, 2015). Meanwhile, teachers can also attend training workshops to update their teaching beliefs and theory-informed teaching approaches (e.g., a Systematic Functional Linguistic genre pedagogy, the visualization and cooperative strategies and critical pedagogical approach) (Shi, Baker \& Chen, 2019; Miller, 2015). Last but not least, institutions should be more proactive in listening to and resolving teaching staff's concerns, thereby persuading teachers from burnout and motivating them to respond more positively to the professional duties.

\section{B. Limitations and Suggestions for Further Research}

There are some limitations to the current study. First, the follow-up interview was merely employed to account for or validate participants' perspectives elicited from the survey when something worth noteworthy was identified, making the findings not descriptive and rich enough. Also, since students' perception of L2 teaching changes constantly, inquiries into students' attitudes towards their teachers as a motivating factor and how their attitudes change over time are accordingly needed in future research. Finally, to inform teaching practice better, the research can take a micro perspective and be designed at the individual classroom level where teachers will take the role of researchers to generate detailed results about students' perspectives on and actual pedagogical effects of the teacher-related motivators. 


\section{REFERENCES}

[1] Alrabai, F. (2016). The effects of teachers' in-class motivational intervention on learners' EFL achievement. Applied Linguistics, 37 (3), 307-333. https://doi.org/10.1093/applin/amu021.

[2] Amiryousefi, M., \& Geld, R. (2019). The role of redressing teachers' instructional feedback interventions in EFL learners' motivation and achievement in distance education, Innovation in Language Learning and Teaching. https://doi.org/10.1080/17501229.2019.1654482.

[3] Borg, S. (2006). The distinctive characteristics of foreign language teachers. Language Teaching Research, 10(1), 3-31.

[4] Cohen, A., \& Dörnyei, Z. (2002). Focus on the language learner: motivation, styles and strategies. In N. Schmitt (Eds.), (pp.170-190), An Introduction to Applied Linguistics. Arnold: Oxford University Press. https://doi.org/10.1111/j.00267902.2005.00263.x.

[5] Csizér, K., \& Dömyei, Z. (2005). The internal structure of language learning motivation and its relationship with language choice and learning effort. The Modern Language Journal, 89, 19-36.

[6] Dömyei, Z., \& Csizér, K. (1998). Ten commandments for motivating language learners: results of an empirical study. Language Teaching Research, 2, 203-229. https://doi.org/10.1177/136216889800200303.

[7] Dömyei, Z. (1994). Motivation and motivating in the foreign language classroom. The Modern Language Journal, 78, $273-284$. https://doi.org/10.1111/j.1540-4781.1994.tb02042.x.

[8] Fithriani, R. (2018). Communicative game-based learning in EFL grammar classroom: suggested activities and students' perception. Journal of English Education and Linguistics Studies, 5(2), 171-188.

[9] Gao, J., \& Huang, J. (2010). On communicative competence in curriculum design: a comparison of the college English curriculum requirements and the English curriculum standards. Polyglossia, 18, 73-86.

[10] Göksel, Ş., \& Rakıcıŏlu-Söylemez, A. (2018). Becoming a professional: Exploring EFL pre-service teachers' conceptions of an effective foreign language teacher. Journal of Language and Linguistic Studies, 14(4), 111-135.

[11] Hamada, Y. (2011). Different demotivators for Japanese junior high and high school learners. Journal of Pan-Pacific Association of Applied Linguistics, 15(1), 15-38.

[12] Hsu, L. (2013). The Relationship between Taiwanese English teacher misbehaviors and college student motivation in English classes. Journal of Applied English, 6, 1-13.

[13] Hu, G. (2002) Potential cultural resistance to pedagogical imports: the case of communicative language teaching in China. Language, Culture and Curriculum, 15(2), 93-105. https://doi.org/10.1080/07908310208666636.

[14] Huang, J., \& Andrews, S. (2010). Situated development and use of language learner strategies: voices from EFL students. Language Learning Journal, 38 (1), 19-35. https://doi.org/10.1080/09571730902717430.

[15] Jacobs, G. E. (2013). Rethinking common assumptions about adolescents' motivation to use technology in and out of school. Journal of Adolescent \& Adult Literacy, 56(4), 271. https://doi.org/10.1002/JAAL.00139.

[16] Jiang, L. J., \& Luk, J. (2016). Multimodal composing as a learning activity in English classrooms: Inquiring into the sources of its motivational capacity. System, 59, 1-11. https://doi.org/10.1016/j.system.2016.04.001.

[17] Kearney, P., Plax, T. G., Hays, E. R., \& Ivey, M. J. (1991). College teacher misbehaviors: what students don't like about what teachers say and do. Communication Quarterly, 39(4), 309-324. https://doi.org/10.1080/01463379109369808.

[18] Kikuchi, K. (2009). Listening to learners' voices: What démotivâtes Japanese high school students? Language Teaching Research, 13, 453-471. https://doi.org/10.1177/1362168809341520.

[19] Kikuchi, K. (2019). Motivation and demotivation over two years: A case study of English language learners in Japan. Studies in Second Language Learning and Teaching, 9 (1). 157-175. http://dx.doi.org/10.14746/ssllt.2019.9.1.7.

[20] Koç, E. M. (2012). Affective characteristics and teaching skills of English language teachers: comparing perceptions of elementary, secondary and high school students. Creative Education, 4(2), 117-123. https://doi.org/10.4236/ce.2013.42017.

[21] Little, D. (1995). Learning as dialogue: the dependence of learner autonomy on teacher autonomy. System, 23(2), 175-181. https://doi.org/10.1016/0346-251X(95)00006-6.

[22] Lee, T. S. O., Gardner, D., \& Lau, K. (2019). The effects of L2 motivational strategies: within and beyond the L2 classroom. Innovation in Language Learning and Teaching. https://doi.org/10.1080/17501229.2019.1620240.

[23] Liu, C. (2020). Motivators for demotivators affecting EFL learners in Chinese secondary vocational school. English Language Teaching, 13(4), 41-51. https://doi.org/10.5539/elt.v13n4p41.

[24] Masgoret, A. M., \& Gardner, R. C. (2003). Attitudes, motivation, and second language learning: a meta-analysis of studies conducted by gardner and associates. Language Learning, 53(1), 123-163. https://doi.org/10.1111/1467-9922.00212.

[25] Matsuda, S., \& Gobel, P. (2004). Anxiety and predictors of performance in the foreign language classroom. System, 32, 21-36. https://doi.org/10.1016/j.system.2003.08.002.

[26] Matsumoto, M. (2011). Second Language learners' motivation and their perception of their teachers as an affecting factor. New Zealand Studies in Applied Linguistics, 17 (2), 37-52.

[27] McEowna, M. S., \& Takeuchi, O. (2014). Motivational strategies in EFL classrooms: how do teachers impact students' motivation? Innovation in Language Learning and Teaching, 8 (1), 20-38. https://doi.org/10.1080/17501229.2012.741133.

[28] Miller, P. (1987). Ten characteristics of a good teacher. English Teaching Forum, $25,40-41$. https://doi.org/10.1119/1.2342147.

[29] Miller, L. (2015). Sports Communication as a way to develop critical competencies in the L2 classroom. RELC Journal, 46(1), 89-104.

[30] Nikitina, L., \& Furuoka, F. (2009). Teacher-student relationship and the conceptualization of the "good language teacher": does culture matter? The Asian EFL Journal Quarterly, 11(2), 163-187.

[31] Oxford, R. L., \& Shearin, J. (1994). Language learning motivation: expanding the theoretical framework. The Modern Language Journal, 78(1), 12-28. https://doi.org/10.1111/j.1540-4781.1994.tb02011.x.

[32] Park, J. K. (2006). Professionalization of TEFL in Korea: The roads behind and ahead. The Journal of Asia TEFL, 3(4), 113134. 
[33] Scott, M., Matthew, M., \& Timothy, M. (2002). Students' motives for communicating with their instructors: considering instructor socio-communicative style, student socio-communicative orientation, and student gender. Communication Education, 51(2), 121-133. https://doi.org/10.1080/03634520216511.

[34] Shi, L. M., Baker, A., \& Chen, H. L. (2019). Chinese EFL teachers' cognition about the effectiveness of genre pedagogy: A case study. RELC Journal, 50(2), 314-332. https://doi.org/10.1177/0033688217716506.

[35] Usman, B., Silviyanti, T. M., \& Marzatillah, M. (2016). The influence of teacher's competence towards the motivation of students in learning English. Studies in English Language and Education, 3(2), $134-146$. https://doi.org/10.24815/siele.v3i2.4961.

[36] Wen, X. (1997). Motivation and language learning with students of Chinese. Foreign Language Annals, 30, $235-250$. https://doi.org/10.1111/j.1944-9720.1997.tb02345.x.

[37] Wen, Q. F. (2015). Developing a theoretical system of production-oriented approach in language teaching. Foreign LanguageTeaching and Research, 47(4), 547-558.

[38] Williams, M., \& Burden, R. (1997). Psychology for language teachers. Cambridge: Cambridge University Press.

[39] Wi, H. J., \& Joh, J. S. (2010). The relationships among English learning motivation, learning strategy, and English achievement: A study of Korean high school students. Korean Journal of English Language and Linguistics, 10(4), 807-838. https://doi.org/10.15738/kjell.10.4.201012.807.

[40] Xiang, M. Y., \& Borg, S. (2014). College English teachers' beliefs about effective language teaching. Asian Journal of English Language Teaching, 24, 97-120.

[41] Zarei, M., Ahour, T., \& Seifoori, Z. (2020). Impacts of implicit, explicit, and emergent feedback strategies on EFL learners' motivation, attitude and perception, Cogent Education, 7(1), 1-17. https://doi.org/10.1080/2331186X.2020.1727130.

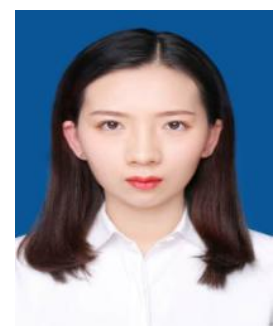

Chang Liu was born in Taiyuan city, Shanxi province, China in 1997. She received her master degree in English studies, TESL from City University of Hong Kong, China in 2020. Her research interests include English teaching, genre analysis and multimodality. 